\title{
Growth and gas production of a novel obligatory heterofermentative Cheddar cheese nonstarter lactobacilli species on ribose and galactose
}

\author{
Fatih Ortakci, ${ }^{,}$Jeffery R. Broadbent, ${ }^{* 1}$ Craig J. Oberg, ${ }^{*} \dagger$ and Donald J. McMahon ${ }^{* 1}$ \\ *Western Dairy Center, Department of Nutrition, Dietetics, and Food Sciences, Utah State University, Logan 84322-8700 \\ †Microbiology Department, Weber State University, Ogden, UT 84408-2506
}

\begin{abstract}
An obligatory heterofermentative lactic acid bacterium, Lactobacillus wasatchii sp. nov., isolated from gassy Cheddar cheese was studied for growth, gas formation, salt tolerance, and survival against pasteurization treatments at $63^{\circ} \mathrm{C}$ and $72^{\circ} \mathrm{C}$. Initially, $L b$. wasatchii was thought to use only ribose as a sugar source and we were interested in whether it could also utilize galactose. We conducted experiments to determine the rate and extent of growth and gas production in carbohydraterestricted (CR) de Man, Rogosa, and Sharpe (MRS) medium under anaerobic conditions with various combinations of ribose and galactose at 12,23 , and $37^{\circ} \mathrm{C}$, with $23^{\circ} \mathrm{C}$ being the optimum growth temperature of Lb. wasatchii among the 3 temperatures studied. When Lb. wasatchii was grown on ribose $(0.1,0.5$, and $1 \%)$, maximum specific growth rates $\left(\mu_{\max }\right)$ within each temperature were similar. When galactose was the only sugar, compared with ribose, $\mu_{\max }$ was 2 to 4 times lower. At all temperatures, the highest final cell densities (optical density at $640 \mathrm{~nm}$ ) of $L b$. wasatchii were achieved in CR-MRS plus $1 \%$ ribose, $0.5 \%$ ribose and $0.5 \%$ galactose, or $1 \%$ ribose and $1 \%$ galactose. Similar $\mu_{\max }$ values and final cell densities were achieved when $50 \%$ of the ribose in CR-MRS was substituted with galactose. Such enhanced utilization of galactose in the presence of ribose to support bacterial growth has not previously been reported. It appears that $L b$. wasatchii co-metabolizes ribose and galactose, utilizing ribose for energy and galactose for other functions such as cell wall biosynthesis. Co-utilization of both sugars could be an adaptation mechanism of $L b$. wasatchii to the cheese environment to efficiently ferment available sugars for maximizing metabolism and growth. As expected, gas formation by the heterofermenter was observed only when galactose was present in the medium. Growth
\end{abstract}

Received December 30, 2014.

Accepted February 8, 2015.

${ }^{1}$ Corresponding authors: Donald.McMahon@usu.edu and Jeff. Broadbent@usu.edu experiments with MRS plus $1.5 \%$ ribose at $\mathrm{pH} 5.2$ or 6.5 with $0,1,2,3,4$, or $5 \% \mathrm{NaCl}$ revealed that $L b$. wasatchii is able to grow under salt and $\mathrm{pH}$ conditions typical of Cheddar cheese (4 to $5 \%$ salt-in-moisture, $\mathrm{pH} \sim 5.2$ ). Finally, we found that $L b$. wasatchii cannot survive low-temperature, long-time pasteurization but survives high-temperature, short-time (HTST) laboratory pasteurization, under which a $4.5 \log$ reduction occurred. The ability of $L b$. wasatchii to survive HTST pasteurization and grow under cheese ripening conditions implies that the presence of this nonstarter lactic acid bacterium can be a serious contributor to gas formation and textural defects in Cheddar cheese.

Key words: nonstarter lactic acid bacteria, late blowing, ribose, cofermentation

\section{INTRODUCTION}

Lactic acid bacteria (LAB) present in ripening cheese include deliberately added starter $\mathrm{LAB}$ and a variety of adventitious $\mathrm{LAB}$ referred to as nonstarter LAB (NSLAB). The NSLAB gain access to cheese through the milk or processing environment (Naylor and Sharpe, 1958; Peterson and Marshall, 1990; Martley and Crow, 1993; Somers et al., 2001).

The predominant NSLAB in Cheddar cheese are facultative heterofermentative (FHF) lactobacilli and, less frequently, pediococci or obligatory heterofermentative (OHF) lactobacilli (Jordan and Cogan, 1993; Crow et al., 2001; Banks and Williams, 2004). Presence of OHF lactobacilli are a particular concern because these microbes may promote the development of undesirable flavor and body defects including gas formation in Cheddar cheese (Dacre, 1953; Laleye et al., 1987; Khalid and Marth, 1990). Unwanted gas formation in Cheddar cheese is a recurrent and widespread problem in the dairy industry that has probably affected most cheese plants (Mullan, 2000). Our group recently isolated a new Lactobacillus species from a "gassy" Cheddar cheese after incubation on de Man, Rogosa, and Sharpe (MRS) agar for $35 \mathrm{~d}$ at $6^{\circ} \mathrm{C}$. This bacterium was designated Lactobacillus wasatchii sp. nov. (our unpublished 
data; GenBank accession number: AWTT00000000 as Lactobacillus spp. WDC04).

Lactobacillus wasatchii is an OHF species and therefore uses the pentose phosphate pathway (PP) to generate energy from pentose and hexose sugars. Its preferred sugar is ribose, although hexoses such as galactose are also a potential energy source in cheese. More importantly, hexose sugars can be fermented by OHF to lactate, acetate or ethanol plus $\mathrm{CO}_{2}$, making Lb. wasatchii a potential contributor to gassy defect in Cheddar cheese.

This study examined growth characteristics of $L b$. wasatchii with respect to ribose and galactose utilization, gas formation, tolerance to the salt and $\mathrm{pH}$ values found in Cheddar cheese, and its ability to survive pasteurization treatments. To our knowledge, this is the first report on growth and gas formation of a slow-growing OHF lactobacillus species isolated as an NSLAB from a "gassy" Cheddar cheese.

\section{MATERIALS AND METHODS}

\section{Materials}

Lactobacilli MRS broth, proteose peptone, polypeptone, beef extract, yeast extract, GasPak EZ gas-generating pouches, and agar were purchased from Becton Dickinson and Co. (Sparks, MD); ribose was donated by Bioenergy Life Science Inc. (Ham Lake, MN), UHT milk was from Gossner Foods Inc. (Logan, UT), Tween-80 and bromocresol purple were from SigmaAldrich Inc. (St. Louis, MO), dipotassium phosphate was from Fisher Scientific Inc. (Fair Lawn, NJ), sodium acetate trihydrate and diammonium citrate were from Mallinckrodt Baker Inc. (Paris, KY), galactose, and triammonium citrate were from Alfa Aesar Inc. (Ward Hill, MA), and magnesium sulfate was from Alfa Aesar Inc. (Heysham, UK).

A carbohydrate-restricted version of MRS (CRMRS) was prepared by omitting glucose from the MRS broth formula. To $2 \mathrm{~L}$ of deionized water was added $20.0 \mathrm{~g}$ of proteose peptone No. 3, $20.0 \mathrm{~g}$ of beef extract, $10.0 \mathrm{~g}$ of yeast extract, $2.0 \mathrm{~g}$ of Tween- $80,4.0 \mathrm{~g}$ of ammonium citrate, $10.0 \mathrm{~g}$ of sodium acetate, $0.2 \mathrm{~g}$ of magnesium sulfate, $0.1 \mathrm{~g}$ of manganese sulfate, and 4.0 $\mathrm{g}$ of dipotassium phosphate. The CR-MRS was supplemented with different levels of ribose and galactose to study the growth properties of $L b$. wasatchii.

\section{Bacterium and Growth}

Stock cultures of $L b$. wasatchii were maintained at $-80^{\circ} \mathrm{C}$ in MRS broth supplemented with $1.5 \%$ ribose (MRS+R) and 10\% glycerol. Working cultures was prepared by 2 successive transfers into $10 \mathrm{~mL}$ of MRS+R broth, with anaerobic incubation using GasPak EZ at $23^{\circ} \mathrm{C}$ for $40 \mathrm{~h}$ after each transfer. Growth of $L b$. wasatchii was evaluated by inoculation of the working culture into $10 \mathrm{~mL}$ of CR-MRS broth acidified to $\mathrm{pH} 5.20$ with $\mathrm{HCl}$ and supplemented with $0.1 \%$ galactose or ribose, $0.5 \%$ galactose or ribose, $1.0 \%$ galactose or ribose, or a 0.50:0.50 combination or 2.0\% sugar (1\% ribose plus $1 \%$ galactose). Optical density of the cell suspensions were followed at $640 \mathrm{~nm}\left(\mathbf{O D}_{640}\right)$ after inoculation and every $12 \mathrm{~h}$ thereafter at 12,23 , or $37^{\circ} \mathrm{C}$ and during anaerobic incubation in jars containing GasPak EZ. Maximum specific growth rate $\left(\boldsymbol{\mu}_{\max }\right)$ was calculated as the slope of the steepest linear portion of the growth rate curves. Broth samples containing Durham tubes were similarly prepared, inoculated, and incubated to test for gas production. Working cultures were prepared in duplicate to conduct growth curves and gas formation experiments.

To test $\mathrm{NaCl}$ tolerance of Lb. wasatchii at $\mathrm{pH} 5.2$ or 6.5, Lb. wasatchii working cultures were prepared in triplicate and inoculated into $\mathrm{MRS}+\mathrm{R}$ broth containing $0,1,2,3,4$, or $5 \%$ (wt/wt) $\mathrm{NaCl}$. Growth at $23^{\circ} \mathrm{C}$ under anaerobic conditions was followed by spectrophotometrical $\left(\mathrm{OD}_{600}\right)$ measurements every $8 \mathrm{~h}$ until the stationary phase was reached.

\section{Thermotolerance}

The ability of $L b$. wasatchii to withstand pasteurization treatment was assayed by heating $9.9 \mathrm{~mL}$ of UHT milk to $63^{\circ} \mathrm{C}$ and $72^{\circ} \mathrm{C}$ in sterile polypropylene tubes. Once the desired temperature was reached, each tube was inoculated with $0.1 \mathrm{~mL}$ of $L b$. wasatchii working culture (prepared in triplicate) containing $\sim 6 \times 10^{8}$ $\mathrm{cfu} / \mathrm{mL}$ and the samples held at $63^{\circ} \mathrm{C}$ and $72^{\circ} \mathrm{C}$ for 30 min or $15 \mathrm{~s}$, respectively. Samples were then placed in a $31^{\circ} \mathrm{C}$ water bath (the set temperature commonly used for making Cheddar cheese) for $2 \mathrm{~h}$. These treatments were designed to mimic the HTST continuous pasteurization used in large-scale cheese operations and the low-temperature, long-time (LTLT) batch pasteurization often used by small-scale artisan cheese makers. Samples were then plated on MRS $+R$ agar in duplicate and incubated at $23^{\circ} \mathrm{C}$ anaerobically for $5 \mathrm{~d}$.

\section{Statistical Analysis}

Statistical analysis of the effect of different temperature, sugar, $\mathrm{pH}$, and $\mathrm{NaCl}$ treatments on $\mu_{\max }$ and final cell density of $L b$. wasatchii were performed using PROC GLM in SAS (version 9.1, SAS Institute, Cary, $\mathrm{NC}$ ), and differences between means were determined 
using REGWQ multiple range test and Tukey least squares means.

\section{RESULTS}

\section{Growth}

Ribose. Growth curves for $L b$. wasatchii at 23, 37, and $12^{\circ} \mathrm{C}$ in CR-MRS with ribose at $\mathrm{pH} 5.20$ are represented in Figures 1A, 2A, and 3A, respectively. Within each temperature, significantly higher $\mu_{\max }$ values were observed when Lb. wasatchii was grown on CR-MRS plus ribose $(P<0.05)$ compared with galactose as the sole sugar (Table 1 ). In the presence of $1 \%$ ribose, $\mu_{\max }$ of $L b$. wasatchii were as follows: $23^{\circ} \mathrm{C}>37^{\circ} \mathrm{C}=12^{\circ} \mathrm{C}$. When Lb. wasatchii was grown in the presence of $1.0 \%$ ribose at 12 and $23^{\circ} \mathrm{C}$, exponential growth continued until final $\mathrm{OD}_{640}$ levels of $\sim 1.3$ to 1.4 were reached (Table 2), with lower $\mathrm{OD}_{640}$ achieved at lower sugar levels, indicating that available sugar was a limiting factor on extent of growth. Less cell growth occurred at $37^{\circ} \mathrm{C}$, with $\mathrm{OD}_{640}$ only reaching 0.75 . Assuming that exponential growth ends when the sugars are depleted, the lower final cell density at $37^{\circ} \mathrm{C}$ may indicate that more of the energy obtained via fermentation is being used to maintain cell viability because of energy-intensive stress responses at the higher temperature.

Galactose. When galactose was the only sugar, growth of $L b$. wasatchii was slow (Figures $1 \mathrm{~B}, 2 \mathrm{~B}$, and $3 \mathrm{~B}$ ), with $\mu_{\max }$ of $<0.01$ at all temperatures (Table 1 ). Final cell densities were lower $(P<0.05)$ than when $L b$. wasatchii was grown with ribose except for the lowest sugar level $(0.1 \%)$ at 12 and $37^{\circ} \mathrm{C}$ (Table 2). Slower utilization of galactose by $L b$. wasatchii in the absence of ribose was expected, as we had previously seen that galactose did not provide a positive response on the API 50 CHL (bioMérieux, Marcy l'Etoile, France) test even when held for longer than $48 \mathrm{~h}$ (our unpublished data). With slower growth occurring when galactose was the only sugar, the stationary phase in CR-MRS plus $0.5 \%$ galactose was only reached after $156 \mathrm{~h}$ at $23^{\circ} \mathrm{C}$ compared with $24 \mathrm{~h}$ in CR-MRS plus $0.5 \%$ ribose. At $37^{\circ} \mathrm{C}$, the extent of bacterial growth remained low (final $\mathrm{OD}_{640} \leq 0.22$ ) even when the galactose level was increased to $1 \%$ (Table 2).

Combined Ribose and Galactose. The $\mu_{\max }$ was not significantly different when a 1:1 blend of galactose and ribose was used compared with ribose alone $(P>$ 0.05 ), with only a slight difference observed for growth at $23^{\circ} \mathrm{C}$ (Figures 1, 2, and 3; Table 1). In general, final cell densities were similar when the total sugar content was the same (Table 2). This indicates that galactose utilization by $L b$. wasatchii is slower when there is no ribose present but that almost the same rate of growth
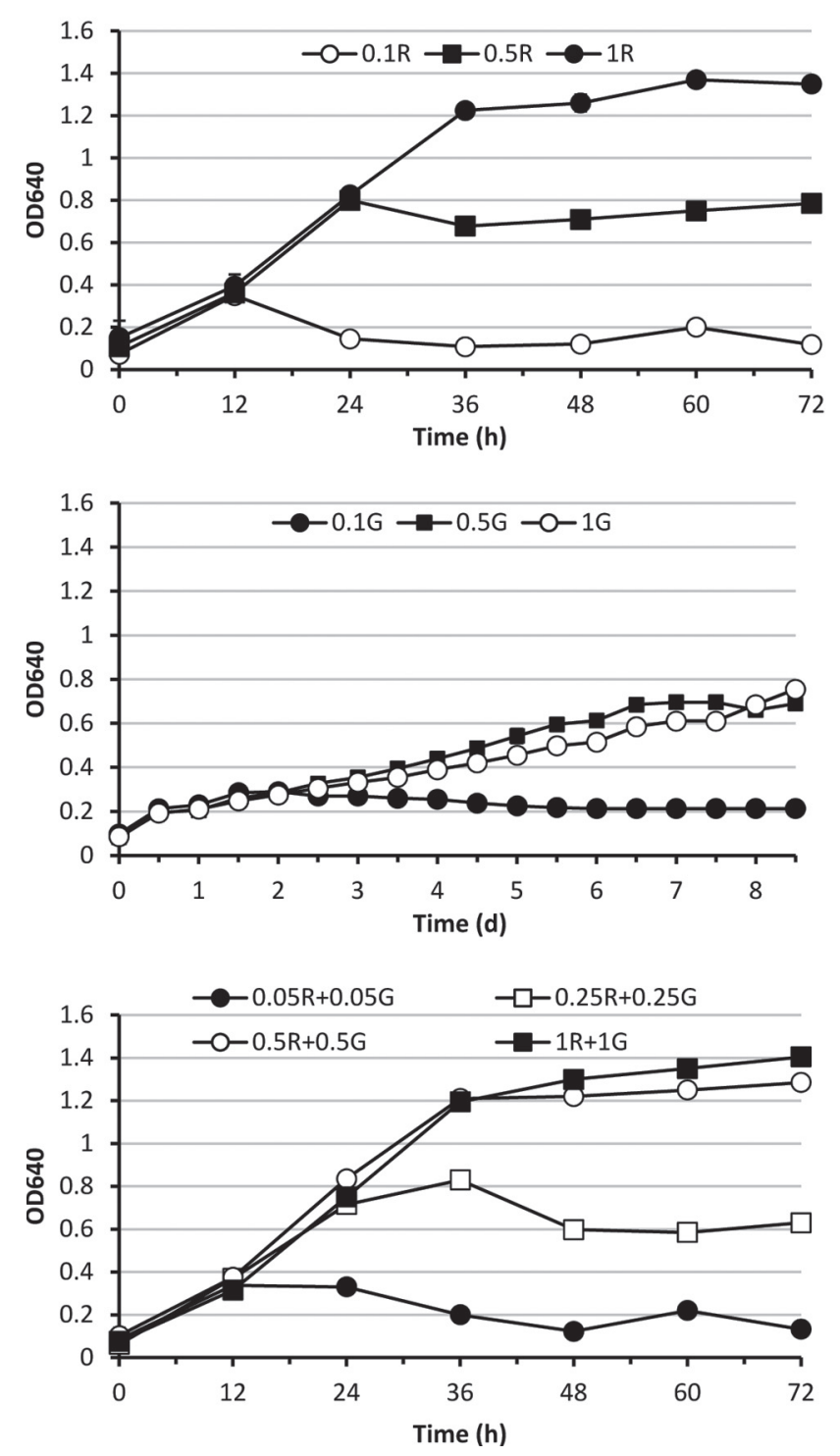

Figure 1. Growth of Lactobacillus wasatchii (optical density at $\left.640 \mathrm{~nm}, \mathrm{OD}_{640}\right)$ at $23^{\circ} \mathrm{C}$ in carbohydrate-restricted de Man, Rogosa, and Sharpe adjusted to $\mathrm{pH} 5.2$ and supplemented with ribose (A), galactose (B), or a mixture of ribose and galactose (C). Numbers for each symbol represent the percentage concentration (wt/vol) of sugar (ribose, R, or galactose, G) added to the medium. Error bars (not visible $)=\operatorname{SE}(n=2)$.

as that with ribose is achieved when both sugars are present.

\section{Salt Tolerance}

The growth characteristics of $L b$. wasatchii grown in MRS+R with 0 to $5 \% \mathrm{NaCl}$ at $\mathrm{pH} 6.5$ and 5.2 are shown in Figures $4 \mathrm{~A}$ and 4B, respectively. After $48 \mathrm{~h}$, an $\mathrm{OD}_{600}$ of 2.0 was reached in all cultures except for $5 \%$ salt at $\mathrm{pH} 5.2$, which had an $\mathrm{OD}_{600}$ of 1.75 and only 

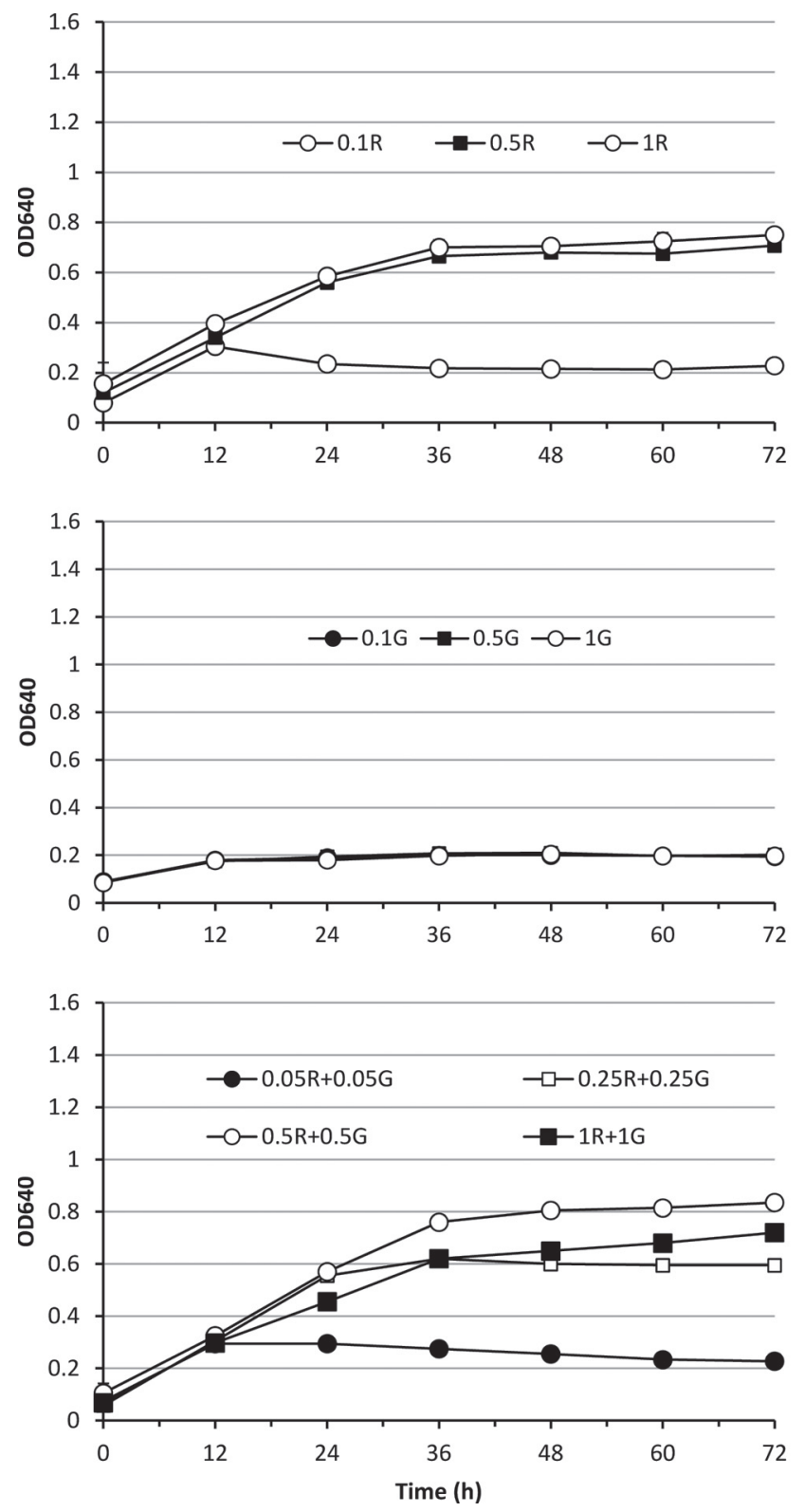

Figure 2. Growth of Lactobacillus wasatchii (optical density at $\left.640 \mathrm{~nm}, \mathrm{OD}_{640}\right)$ at $37^{\circ} \mathrm{C}$ in carbohydrate-restricted de Man, Rogosa, and Sharpe adjusted to $\mathrm{pH} 5.2$ and supplemented with ribose (A), galactose (B), or a mixture of ribose and galactose (C). Numbers for each symbol represent the percentage concentration (wt/vol) of sugar (ribose, R, or galactose, G) added to the medium. Error bars (not visible $)=\operatorname{SE}(\mathrm{n}=2)$.

reached $\mathrm{OD}_{600}$ of 2.0 after $60 \mathrm{~h}$. At $\mathrm{pH} 6.5$, we observed a slight decrease in $\mu_{\max }$ when $L b$. wasatchii was grown with $4 \% \mathrm{NaCl}$, although this was not observed with $5 \%$ $\mathrm{NaCl}$ (Table 3). At pH 5.2, $\mu_{\max }$ was significantly lower at both 4 and $5 \% \mathrm{NaCl}(P<0.05)$. Final cell densities were the same $\left(\mathrm{OD}_{600}=2.0\right)$ except for $5 \% \mathrm{NaCl}$, which had a final $\mathrm{OD}_{600}$ of $1.96(P<0.05)$. A combination

B
A
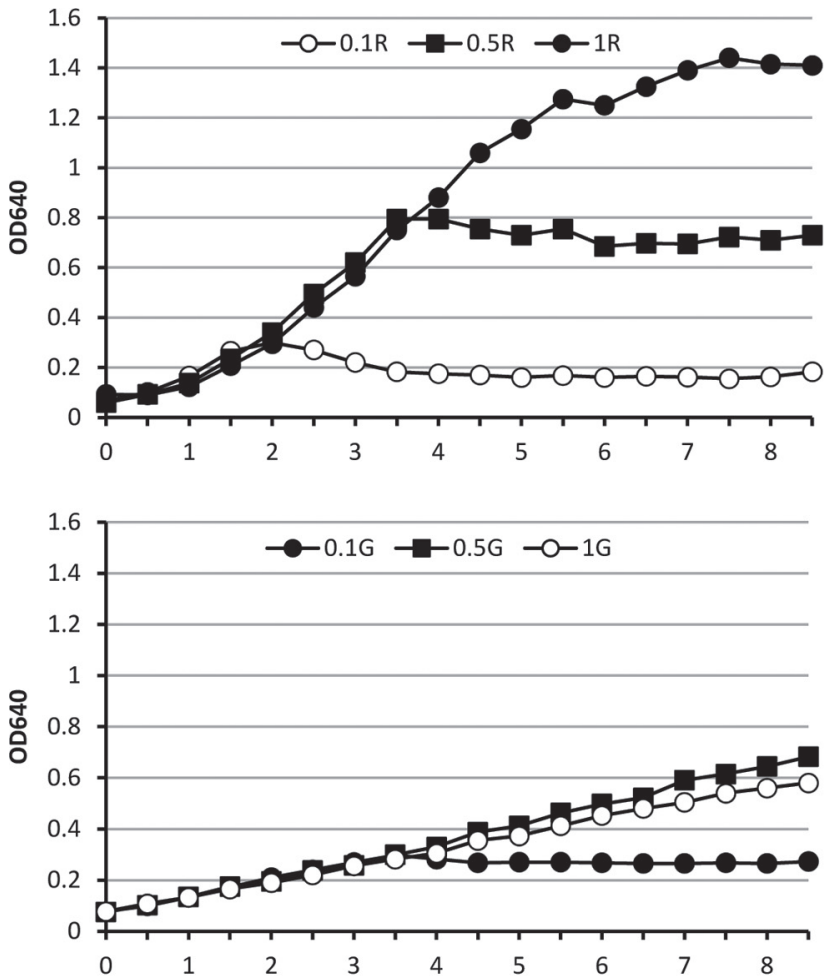

B

C

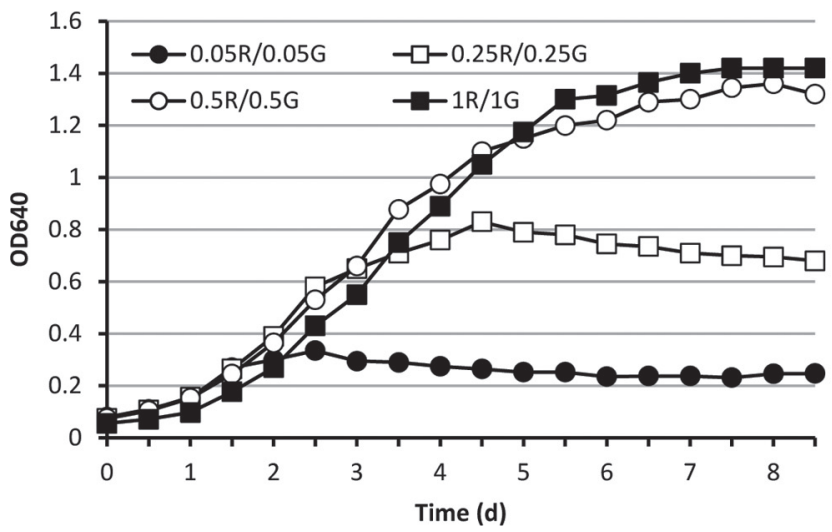

C

Figure 3. Growth of Lactobacillus wasatchii (optical density at $\left.640 \mathrm{~nm}, \mathrm{OD}_{640}\right)$ at $12^{\circ} \mathrm{C}$ in carbohydrate-restricted de Man, Rogosa, and Sharpe adjusted to $\mathrm{pH} 5.2$ and supplemented with ribose (A), galactose (B), or a mixture of ribose and galactose (C). Numbers for each symbol represent the percentage concentration (wt/vol) of sugar (ribose, R, or galactose, G) added to the medium. Error bars (not visible $)=\operatorname{SE}(n=2)$.

of salt and lower $\mathrm{pH}$ causes a decrease in $\mu_{\max }$, but $L b$. wasatchii can grow in the same environment that occurs during Cheddar cheese ripening $(\sim \mathrm{pH} 5.2,4$ to $5 \%$ salt-in-moisture). Such salt tolerance is expected for NSLAB isolated from Cheddar cheese, Jordan and Cogan (1993) observed growth of NSLAB such as Lactobacillus casei, Lb. plantarum, and Lb. curvatus in $6 \%$ and some up to $8 \%$ (wt/wt) NaCl. Typically, at least 
Table 1. Maximum specific growth rate $\left(\mu_{\max }\right.$, measured as optical density at $640 \mathrm{~nm}$ per hour, $\left.\mathrm{OD}_{640} / \mathrm{h}\right)$ of Lactobacillus wasatchii at 12,23 , or $37^{\circ} \mathrm{C}$ when grown in carbohydrate-restricted de Man, Rogosa, and Sharpe broth with various levels of ribose and galactose

\begin{tabular}{|c|c|c|c|c|}
\hline \multicolumn{2}{|c|}{ Sugar $(\%$ wt/vol $)$} & \multicolumn{3}{|c|}{$\mu_{\max }\left(\mathrm{OD}_{640} / \mathrm{h}\right)$} \\
\hline Ribose & Galactose & $12^{\circ} \mathrm{C}$ & $23^{\circ} \mathrm{C}$ & $37^{\circ} \mathrm{C}$ \\
\hline 0.1 & 0 & $0.0085^{\text {hij }}$ & $0.0235^{\mathrm{cd}}$ & $0.019^{\mathrm{de}}$ \\
\hline 0.5 & 0 & $0.0145^{\text {efghi }}$ & $0.0365^{\mathrm{a}}$ & $0.0195^{\mathrm{de}}$ \\
\hline 1.0 & 0 & $0.0155^{\text {efgh }}$ & $0.0355^{\mathrm{ab}}$ & $0.0215^{\mathrm{de}}$ \\
\hline 0 & 0.1 & $0.003^{j}$ & $0.0095^{\text {ghij }}$ & $0.008^{\mathrm{ij}}$ \\
\hline 0 & 0.5 & $0.006^{\mathrm{j}}$ & $0.0095^{\text {ghij }}$ & $0.0075^{\mathrm{ij}}$ \\
\hline 0 & 1.0 & $0.005^{\mathrm{j}}$ & $0.009^{\text {ghij }}$ & $0.008^{\mathrm{ij}}$ \\
\hline 0.05 & 0.05 & $0.010^{\text {fghij }}$ & $0.021^{\mathrm{de}}$ & $0.0185^{\mathrm{de}}$ \\
\hline 0.25 & 0.25 & $0.016^{\mathrm{efg}}$ & $0.0285^{\mathrm{bc}}$ & $0.021^{\mathrm{e}}$ \\
\hline 0.5 & 0.5 & $0.018^{\text {de }}$ & $0.0385^{\mathrm{a}}$ & $0.0205^{\mathrm{de}}$ \\
\hline 1.0 & 1.0 & $0.017^{\text {def }}$ & $0.0375^{\mathrm{a}}$ & $0.0195^{\mathrm{de}}$ \\
\hline
\end{tabular}

${ }^{\mathrm{a}-\mathrm{j}}$ Mean values with the same letter are not significantly different from each other $(\alpha=0.05)$.

$6 \%$ salt is needed to slow growth of NSLAB (Lane et al., 1997) and even then, NSLAB populations in Cheddar cheese still reached about the same numbers at all salt levels (2.8 to $6.1 \%$, salt-in-moisture) after 6 mo of storage. It is interesting to note that strains of Lactobacillus danicus, the NSLAB that is phylogenetically closest to $L b$. wasatchii, was susceptible to salt; it had negligible growth at $4 \% \mathrm{NaCl}$ and did not grow at $6.5 \%$ $\mathrm{NaCl}$ (Kask et al., 2003).

\section{Gas Formation}

Gas formation by $L b$. wasatchii was only observed when galactose was present in the media. No gas formation was observed at $23^{\circ} \mathrm{C}$ when the sole sugar source was ribose or when the total sugar concentration, both ribose and galactose, was below $0.5 \%$. At $12^{\circ} \mathrm{C}$, no gas formation was observed at sugar contents of $<1.0 \%$. This may be because of the higher solubility of $\mathrm{CO}_{2}$ at lower temperatures (CRC, 2009). At $37^{\circ} \mathrm{C}$, gas for- mation was only detected in CR-MRS containing $1 \%$ ribose plus $1 \%$ galactose.

\section{Thermotolerance}

Subjecting Lb. wasatchii to HTST treatment $\left(72^{\circ} \mathrm{C}\right.$ for $15 \mathrm{~s})$ resulted in a $\sim 4.5-\log$ reduction, from $6 \times$ $10^{6} \mathrm{cfu} / \mathrm{mL}$ to $9.2 \times 10^{1} \mathrm{cfu} / \mathrm{mL}$ surviving after cooling to $31^{\circ} \mathrm{C}$. In contrast, no detectable colonies of $L b$. wasatchii (i.e., $<10^{1} \mathrm{cfu} / \mathrm{ml}$ ) were found after the LTLT treatment $\left(63^{\circ} \mathrm{C}\right.$ for $\left.30 \mathrm{~min}\right)$. Survival of lactobacilli after milk pasteurization has been previously reported and underscores the potential for lactobacilli in milk to be a source of NSLAB in cheese made from pasteurized milk (Turner et al., 1986; Golnazarian, 2001; Beresford et al., 2001). The finding that Lb. wasatchii can withstand HTST indicates that the bacterium could gain access to cheese directly or produce biofilms in the cheese-processing environment that provide a regular source of contamination.

Table 2. Final cell density of Lactobacillus wasatchii measured as optical density at $640 \mathrm{~nm}\left(\mathrm{OD}_{640}\right)$ when grown at 12,23 , or $37^{\circ} \mathrm{C}$ in carbohydrate-restricted de Man, Rogosa, and Sharpe broth

\begin{tabular}{|c|c|c|c|c|}
\hline \multicolumn{2}{|c|}{ Sugar $(\% \mathrm{wt} / \mathrm{vol})$} & \multicolumn{3}{|c|}{ Final cell density ${ }^{1}\left(\mathrm{OD}_{640}\right)$} \\
\hline Ribose & Galactose & $12^{\circ} \mathrm{C}$ & $23^{\circ} \mathrm{C}$ & $37^{\circ} \mathrm{C}$ \\
\hline 0.1 & 0 & $0.3^{\mathrm{j}}$ & $0.35^{\mathrm{j}}$ & $0.225^{\mathrm{kl}}$ \\
\hline 0.5 & 0 & $0.795^{\text {de }}$ & $0.8^{\mathrm{de}}$ & $0.705^{\mathrm{fg}}$ \\
\hline 1.0 & 0 & $1.44^{\mathrm{a}}$ & $1.37^{\mathrm{b}}$ & $0.75^{\mathrm{ef}}$ \\
\hline 0 & 0.1 & $0.298^{\mathrm{j}}$ & $0.214^{1}$ & $0.205^{1}$ \\
\hline 0 & 0.5 & $0.68^{\mathrm{gh}}$ & $0.69^{\mathrm{fgh}}$ & $0.215^{1}$ \\
\hline 0 & 1.0 & $0.58^{\mathrm{i}}$ & $0.755^{\mathrm{ef}}$ & $0.195^{1}$ \\
\hline 0.05 & 0.05 & $0.335^{\mathrm{j}}$ & $0.335^{\mathrm{j}}$ & $0.300^{\mathrm{j}}$ \\
\hline 0.25 & 0.25 & $0.83^{\mathrm{d}}$ & $0.83^{\mathrm{d}}$ & $0.62^{\text {hi }}$ \\
\hline 0.5 & 0.5 & $1.36^{\mathrm{b}}$ & $1.285^{\mathrm{c}}$ & $0.835^{\mathrm{d}}$ \\
\hline 1.0 & 1.0 & $1.42^{\mathrm{ab}}$ & $1.4^{\mathrm{ab}}$ & $0.72^{\mathrm{fg}}$ \\
\hline
\end{tabular}

${ }^{\mathrm{a}-\mathrm{l}}$ Mean values with the same letter are not significantly different from each other $(\alpha=0.05)$.

${ }^{1}$ Measured as $\mathrm{OD}_{640}$ after incubation for $72 \mathrm{~h}$ for growth at 23 and $37^{\circ} \mathrm{C}$ for medium containing ribose, and after $204 \mathrm{~h}$ for all samples incubated at $12^{\circ} \mathrm{C}$ and those with only galactose at 23 and $37^{\circ} \mathrm{C}$. 
Table 3. Maximum specific growth rate $\left(\mu_{\max }\right.$, measured as optical density at $600 \mathrm{~nm}$ per hour, $\mathrm{OD}_{600} / \mathrm{h}$ ) of Lactobacillus wasatchii cells grown at $23^{\circ} \mathrm{C}$ in de Man, Rogosa, and Sharpe broth supplemented with $1.5 \%$ ribose as a function of salt and $\mathrm{pH}$

\begin{tabular}{lll}
\hline & \multicolumn{2}{c}{$\mu_{\max }\left(\mathrm{OD}_{600} / \mathrm{h}\right)$} \\
\cline { 2 - 3 }$(\% \mathrm{wt} / \mathrm{wt})$ & $\mathrm{pH} 5.2$ & $\mathrm{pH} 6.5$ \\
\hline 0 & $0.05^{\text {cde }}$ & $0.061^{\mathrm{abcd}}$ \\
1 & $0.064^{\mathrm{abc}}$ & $0.076^{\mathrm{a}}$ \\
2 & $0.058^{\mathrm{bcde}}$ & $0.056^{\mathrm{bcde}}$ \\
3 & $0.057^{\mathrm{bcde}}$ & $0.068^{\mathrm{ab}}$ \\
5 & $0.044^{\mathrm{e}}$ & $0.048^{\text {de }}$ \\
\hline
\end{tabular}

${ }^{a-e}$ Mean values with the same letter are not significantly different from each other $(\alpha=0.05)$.

\section{DISCUSSION}

\section{Metabolic Capability}

Lactobacillus wasatchii sp. nov. is an OHF lactobacilli closely related to $L b$. suebicus (isolated from apple and pear mashes), $L b$. vaccinostercus (isolated from cow dung), Lb. hokkaidonensis (isolated from timothy grass silage), Lb. oligofermentans (isolated from poultry), and $L b$. danicus (isolated from cheese). None of these species is regularly isolated from cheese, which could be because NSLAB isolation methods do not incorporate the low-temperature, long-time conditions used to isolate Lb. wasatchii and Lb. danicus (Kask et al., 2003; Oberg et al., 2011; Broadbent et al., 2013). Because its closest phylogenetic relatives are associated with plant materials and cow dung, we speculate that the origin of $L b$. wasatchii was a dairy farm.

Lactobacillus wasatchii is an OHF lactobacillus possessing genes encoding phosphoketolase but lacking the genes encoding fructose-1,6-diphosphate aldolase. Thus, Lb. wasatchii ferments pentose and hexose sugars through the PP. Utilization of hexoses by OHF lactobacilli results in $\mathrm{CO}_{2}$, lactate, and acetate or ethanol production, whereas pentose metabolism does not yield $\mathrm{CO}_{2}$ (Axelsson, 2004). An OHF lifestyle corresponds with the finding that gas formation was only observed when Lb. wasatchii was grown in CR-MRS plus galactose or CR-MRS plus ribose and galactose.

Compared with common cheese NSLAB that are FHF lactobacilli, Lb. wasatchii preferentially utilizes ribose over glucose and other sugars. Slow utilization of hexoses and active fermentation of pentoses was also reported for the OHF Lb. vaccinostercus Kozaki and Okada sp. nov. strains that were isolated from cow dung using a medium containing xylose as the sole carbon source (Okada et al., 1978). Another phylogenetic relative of $L b$. wasatchii, Lb. oligofermentans sp. nov., also utilized glucose very weakly (Koort et al., 2005).
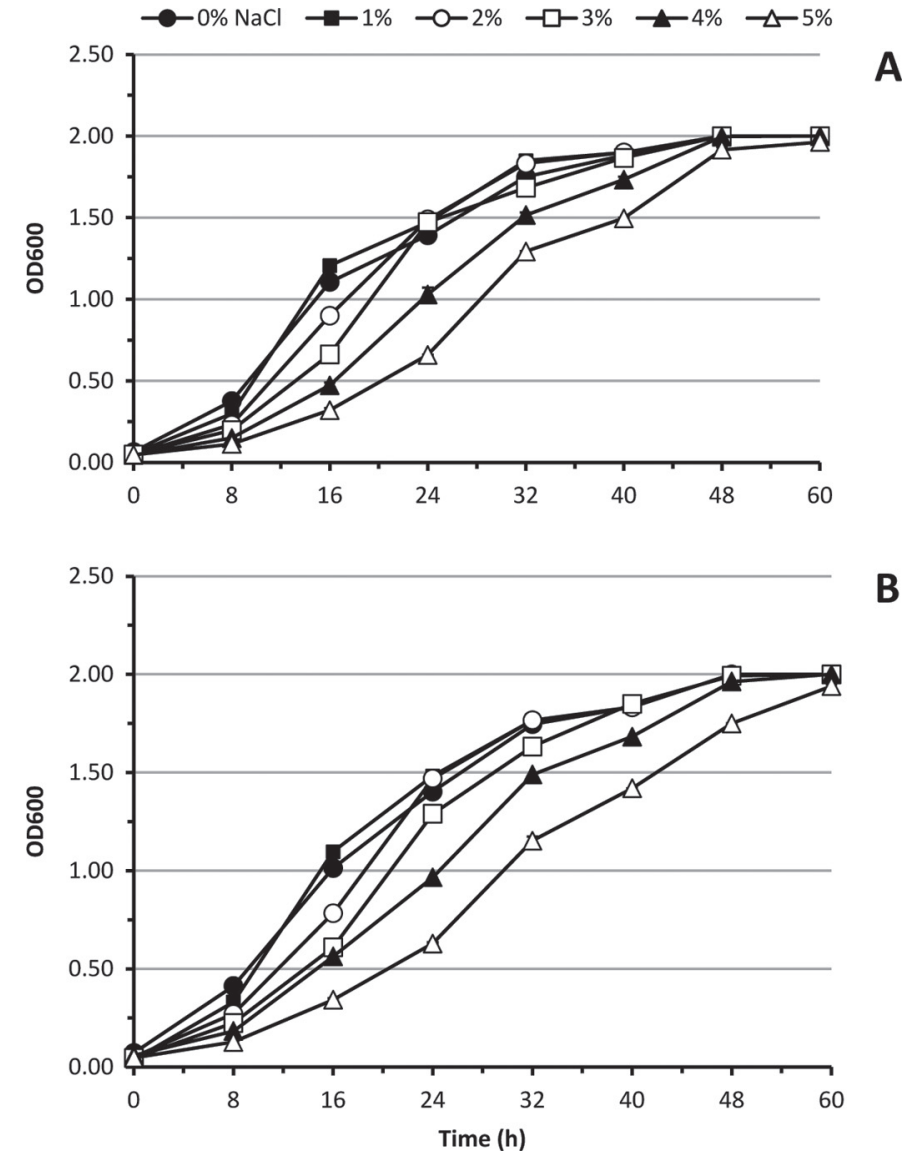

B

Figure 4. Growth of Lactobacillus wasatchii (optical density at $\left.600 \mathrm{~nm}, \mathrm{OD}_{600}\right)$ in regular de Man, Rogosa, and Sharpe broth supplemented with $1.5 \%$ ribose (wt/vol) plus 0 to $5 \% \mathrm{NaCl}$ and adjusted to $\mathrm{pH} 6.5(\mathrm{~A})$ or $\mathrm{pH} 5.2(\mathrm{~B})$. Error bars (not visible) $=\mathrm{SE}(\mathrm{n}=3)$.

\section{Ribose Fermentation}

The heterolactic fermentation of ribose results in a slightly different end-product pattern compared with galactose fermentation. $\mathrm{No}^{\mathrm{CO}_{2}}$ is formed and, because no dehydrogenation steps are necessary to reach the intermediate xylulose-5-phosphate, the reduction of acetylphosphate to ethanol to regenerate $\mathrm{NAD}^{+}$becomes redundant. Instead, acetylphosphate can be converted by acetate kinase in a substrate-level phosphorylation step to acetate and ATP. Fermentation of ribose thus leads to production of equimolar amounts of lactic acid and acetic acid and net $2 \mathrm{~mol}$ ATP $/ \mathrm{mol}$ ribose consumed (Axelsson, 2004).

Two amino sugars that are precursors to the peptidoglycan are $N$-acetylglucosamine and $N$-acetylmuramic acid. Both amino sugars are made from fructose6-phosphate (F6P) that acts as the backbone molecule for cell wall synthesis (White, 2007). Lactobacillus wasatchii possesses a gene encoding transketolase 
that condenses 2 pentoses, with $\mathrm{F} 6 \mathrm{P}$ being one of the metabolic outputs with the remaining carbons eventually being converted into gylceraldehyde-6-phosphate. Based on this information, we speculate that when $L b$. wasatchii is grown in CR-MRS plus ribose, ribose is utilized for both cell wall synthesis and ATP generation to support cell division, as shown in Figure 5 (pathway directions $\{1\},\{2\}$, and $\{3\}$ ).

The $\mu_{\max }$ of $L b$. wasatchii is generally the same at higher concentrations of ribose as at lower concentrations. Thus, PP was operating as fast as possible in generating energy when $L b$. wasatchii was grown in CRMRS with either ribose concentration. It is interesting that similar $\mu_{\max }$ values were achieved when a ribose- galactose mixture was used, even at the low level of $0.05 \%$ ribose plus $0.05 \%$ galactose (Table 1 ). The only notable change that was seen with the increasing sugar concentration was that the time over which exponential growth occurred was lengthened and a higher final cell density was attained.

\section{Galactose Fermentation}

Lactobacillus wasatchii grew very slowly when galactose was the sole carbohydrate source of energy $\left(\mu_{\max }=\right.$ $0.005,0.009$, and 0.008 on $1 \%$ galactose at 12,23 , and $37^{\circ} \mathrm{C}$, respectively). At $37^{\circ} \mathrm{C}, \mathrm{Lb}$. wasatchii showed only limited growth with a final $\mathrm{OD}_{640}$ of $\sim 0.2$ reached when

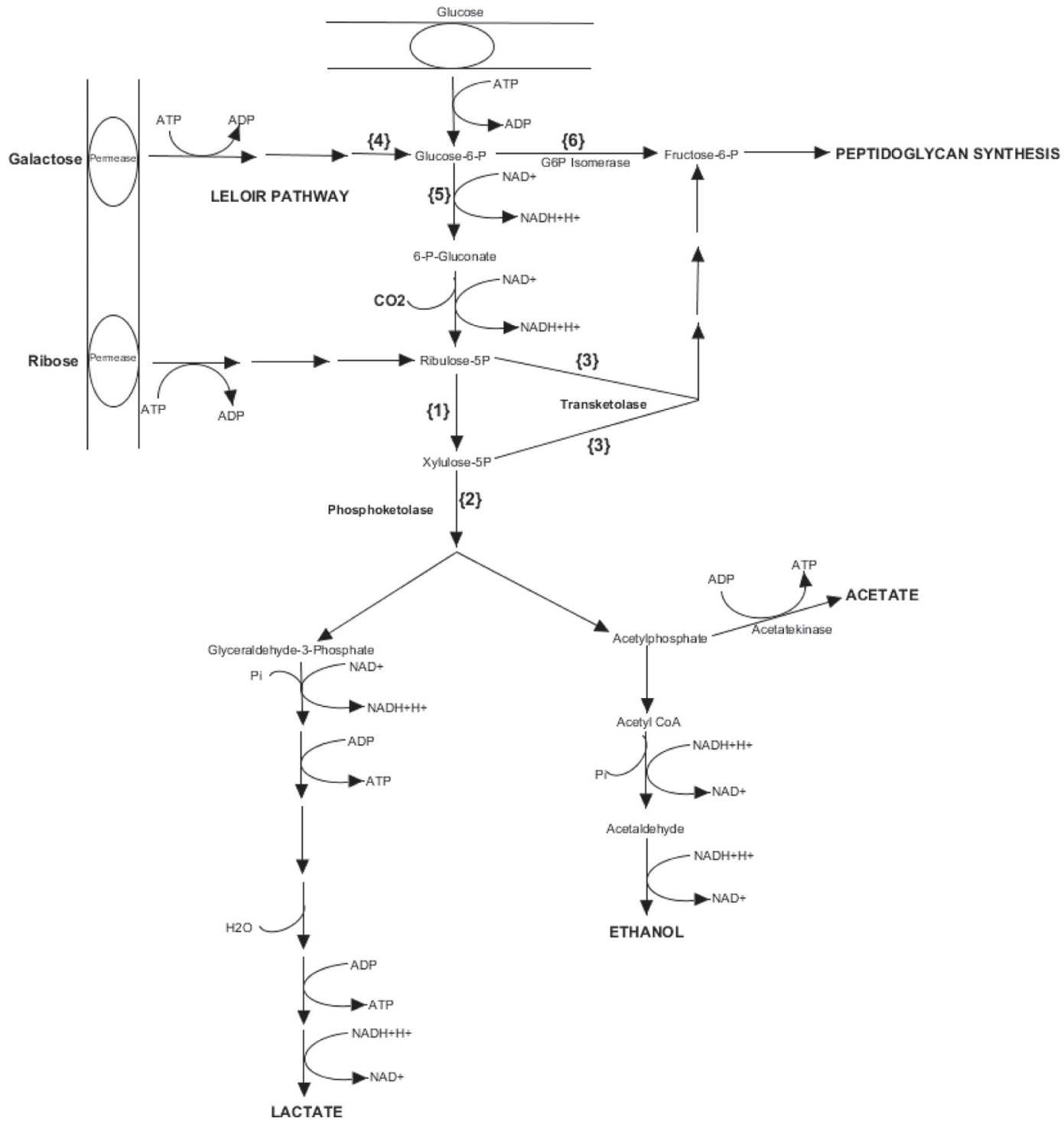

Figure 5. Proposed pathways for ribose and galactose utilization by Lactobacillus wasatchii. $\mathrm{P}=$ phosphate group. Steps $\{1\}$ through $\{6\}$ are described in text. 
galactose was the sole sugar $(0.1 \%$ vs. $1 \%)$. It is interesting that $L b$. wasatchii reached significantly higher final cell densities when grown on $\geq 0.5 \%$ galactose at 12 and $23^{\circ} \mathrm{C}$ versus $37^{\circ} \mathrm{C}(P<0.05)$. The significantly lower final cell density at $37^{\circ} \mathrm{C}$ may be due to more of the ATP produced by fermentation being utilized to sustain cell viability because of energy-intensive stress responses at the higher temperature. Similar results were found by Adamberg et al. (2005), who reported slower growth of $L b$. danicus with glucose or galactose at $30^{\circ} \mathrm{C}$ compared with $24^{\circ} \mathrm{C}$. However, ribose utilization rates by $L b$. danicus were the same at both temperatures. In comparison, utilization of hexose sugars by $L b$. casei or paracasei was higher at $30^{\circ} \mathrm{C}$ compared with $24^{\circ} \mathrm{C}$, whereas ribose utilization did not change (Adamberg et al., 2005).

Analysis of the Lb. wasatchii genome suggests that galactose enters the cell via a permease and is then fermented into the Leloir pathway and converted to glucose-6-phosphate (G6P), as shown in Figure 5. The G6P is then utilized using PP via dehydrogenation to 6-phosphogluconate, followed by decarboxylation to ribulose-5-phosphate $(\mathbf{R} 5 \mathbf{P})$ and $\mathrm{CO}_{2}$ (pathway directions $\{4\},\{5\},\{1\},\{2\})$. Both of these steps require reduction of $\mathrm{NAD}^{+}$to $\mathrm{NADH}$.

The R5P can then be further metabolized in the PP to lactate and acetate or ethanol with the potential to generate up to net 2 ATP. However, the need to reoxidize NADH may direct the pathway from acetylphosphate toward ethanol production rather than acetate. Thus, galactose utilization through the Leloir and PP pathways would supply $1 \mathrm{~mol}$ each of lactic acid, ethanol, and $\mathrm{CO}_{2}$, and net $1 \mathrm{~mol} \mathrm{ATP} / \mathrm{mol}$ of galactose (Axelsson, 2004).

The two possible explanations for the much slower growth of $L b$. wasatchii on galactose compared with ribose are (1) that there is a rate-limiting step in the pathways leading to conversion of galactose into R5P, or (2) that the need to reoxidize NADH requires conversion of acetylphospate into ethanol rather than acetate so that only $1 \mathrm{~mol}$ of ATP per mole of galactose is produced, as reported by Axelsson (2004).

\section{Co-Metabolism of Galactose with Ribose}

There have been a few instances in which the growth of lactobacilli is increased in the presence of 2 sugars compared with either of the sugars alone. Gobetti et al. (1995) reported that a fructose-negative strain of Lactobacillus sanfrancisco (another OHF species) grows faster when it co-ferments fructose in the presence of maltose; maltose is consumed for energy and fructose serves as an external electron acceptor for reoxidation of NADH. This does not seem to be the case for $L b$. wasatchii because neither galactose nor ribose is known to function as an external electron acceptor.

In general, FHF lactobacilli such as Lb. plantarum can utilize both pentoses and hexoses, although Westby (1989) and Westby et al. (1993) reported a strain of Lb. plantarum (NCIMB 8026) that was unable to utilize ribose in the absence of glucose. They offered 2 hypotheses to explain this observation: (1) Lb. plantarum NCIMB 8026 lacks the pathways to produce F6P from pentose sugars through transketolase or via fructose-1,6-bisphosphatase, and thus is unable to make $\mathrm{C}_{6}$ units from $\mathrm{C}_{5}$ sugars and needs an external source of $\mathrm{C}_{6}$ units for biosynthesis of peptidoglycan and other cell building blocks; or (2) that phosphoenolpyruvate (PEP) production during pentose metabolism (compared with hexose fermentation via glycolysis) in $L b$. plantarum NCIMB 8026 is insufficient to support the PEP-dependent uptake of ribose. According to Neidhardt et al. (1990), only one PEP molecule is produced per ribose molecule metabolized (vs. 2 PEP molecules per glucose), leaving no PEP molecules for the other cellular functions such as peptidoglycan synthesis.

With $L b$. wasatchii, transketolase is available to convert pentoses into $\mathrm{F} 6 \mathrm{P}$, thus producing the needed $\mathrm{C}_{6}$ building blocks for peptidoglycan. In addition, for Lb. wasatchii, the uniqueness is improved utilization of a hexose in the presence of a pentose rather than the other way around. Therefore, neither of these hypotheses explains the mechanism of galactose and ribose co-utilization by $L b$. wasatchii (which appears highly adapted to ferment ribose). Ribose metabolism in $L b$. wasatchii is more profitable than galactose (or other hexose) fermentation in terms of energy production. Fred et al. (1921) reported that certain groups of pentose-fermenting LAB commonly found in silage, sauerkraut, and related substances showed high acid production from pentose sugars, whereas hexose sugars yielded low acid but high ethanol production. Once again, this observation is probably a reflection of the substrate energetics; with 2 ATP per pentose but only 1 ATP from hexoses due to the need to reoxidize NADH to $\mathrm{NAD}^{+}$using the ethanol branch of PP.

To explain growth attributes of $L b$. wasatchii during co-utilization of ribose and galactose, it is necessary to consider the potential fates of each sugar with regard to energy yield and cellular building blocks. Because similar $\mu_{\max }$ and final cell densities were observed when Lb. wasatchii was grown in the presence of ribose plus galactose or ribose alone, the rates of energy production and cell wall synthesis are likely the same. Given that Lb. wasatchii has the gene for $\mathrm{G} 6 \mathrm{P}$ isomerase, it can convert G6P to $\mathrm{F} 6 \mathrm{P}$ and utilizes galactose as a ready source of hexose for peptidoglycan synthesis (Figure 5, pathway directions $\{4\},\{6\})$. 
In a parallel manner, final cell densities of $L b$. wasatchii were identical for cells grown in ribose or with $50 \%$ of the ribose replaced with galactose (except for $0.5 \%$ ribose vs. $0.25 \%$ ribose plus $0.25 \%$ galactose at $23^{\circ} \mathrm{C}$ ). This further suggests that only ribose is being used for energy production and that an insignificant amount of ribose is being diverted for peptidoglycan synthesis by transketolase conversion of pentoses to F6P (Figure 5, pathway directions $\{1\},\{2\}$ ). This hypothesis is supported by findings in Bifidobacterium breve, where Degnan and McFarlane (1991) found cells grown in the presence of ${ }^{14} \mathrm{C}$ arabinose (a pentose) and glucose (a hexose) did not incorporate carbon from arabinose into cellular macromolecules.

We propose that when an OHF LAB such as $L b$. wasatchii has both ribose and hexoses available for growth, the ribose is primarily utilized for ATP production via the lower portion of the PP (Figure 5, pathway directions $\{1\},\{2\})$, whereas the hexose is utilized for synthesis of peptidoglycans and other cellular macromolecules (Figure 5, pathway directions $\{4\},\{6\}$ ). This has the advantage of maximizing ATP production, as the need to reoxidize NADH is minimized when only ribose is fermented. The extent of ribose that is diverted from the PP for peptidoglycan synthesis would depend on the relative amounts of hexoses present. A consequence of such simultaneous co-metabolism is that acetate would be expected as the end produce rather than ethanol from acetylphosphate. When ribose is depleted, then galactose would need to be fermented down the $\mathrm{PP}$ to provide energy to the cell. This corresponds with our observations that gas production occurred toward the end of exponential growth or early stationary phase (after $48 \mathrm{~h}$ at $23^{\circ} \mathrm{C}$ ).

Our results clearly demonstrate that $L b$. wasatchii can co-utilize ribose and galactose, which are 2 potential substrates for NSLAB (Tinson et al., 1982; Thomas, 1987; Rapposch et al., 1999; Michel and Martley, 2001) in Cheddar cheese. We also have shown that $L b$. wasatchii is quite tolerant to the salt and $\mathrm{pH}$ conditions that usually exist in ripening Cheddar cheese. The ability to readily consume mixed putative cheese sugars, grow at cheese ripening temperatures, and survive in the harsh environment of cheese support our hypothesis that $L b$. wasatchii contributes late gas-blowing and textural defects in Cheddar cheese. To better understand the adaptation of Lb. wasatchii to the cheese microenvironment, it would be desirable to study whether other sugars in milk and cheese (e.g., lactose, $\quad N$-acetylgalactosamine, $N$-acetylneuraminic acid, mannose, fucose, $\mathrm{N}$-acetylglucosamine) can also be co-utilized by $L b$. wasatchii in the presence of ribose. When describing carbohydrate utilization abilities of bacteria, such co-utilization should also be considered because our initial testing of $L b$. wasatchii led us to believe that it was not capable of utilizing galactose.

\section{CONCLUSIONS}

A new obligatory heterofermentative nonstarter lactic acid bacterium, Lactobacillus wasatchii sp. nov. (isolated from a blown Cheddar cheese) was shown to require ribose for rapid growth, unlike other cheese NSLAB that grow well on glucose. Due to its OHF nature, Lb. wasatchii utilizes 6- and 5-carbon sugars through the pentose phosphate pathway. Fermentation of hexoses such as galactose will produce $\mathrm{CO}_{2}$, so $\mathrm{OHF}$ have been implicated in late blowing of Cheddar cheese. We speculate that when ribose and galactose are both available, $L b$. wasatchii uses ribose to produce energy and galactose for peptidoglycan synthesis and growth. This capability is well suited to cheese ripening and we have shown that $L b$. wasatchii can grow under cheeselike stress conditions of low $\mathrm{pH}(5.2)$ and at least up to $5 \%$ salt content. It also has the potential to survive the HTST pasteurization used in large-scale dairy processing, which may explain how it gains entry to the milk-processing environment.

\section{REFERENCES}

Adamberg, K., M. Antonsson, F. K. Vogensen, E. W. Nielsen, S. Kask, P. L. Møller, and Y. Ardö. 2005. Fermentation of carbohydrates from cheese sources by nonstarter lactic acid bacteria isolated from semi-hard Danish cheese. Int. Dairy J. 15:873-882.

Axelsson, L. T. 2004. Lactic acid bacteria: Classification and physiology. Pages 1-63 in Lactic Acid Bacteria. S. Salminen and A. von Wright, ed. Marcel Dekker, New York, NY.

Banks, J. M., and A. G. Williams. 2004. The role of nonstarter lactic acid bacteria in Cheddar cheese ripening. Int. J. Dairy Technol. 57:145-152.

Beresford, T. P., N. A. Fitzsimons, N. L. Brennan, and T. M. Cogan. 2001. Recent advances in cheese microbiology. Int. Dairy J. $11: 259-274$.

Broadbent, J. R., C. Brighton, D. J. McMahon, N. Farkye, M. Johnson, and J. Steele. 2013. Microbiology of Cheddar cheese made with different fat contents using a Lactococcus lactis single-strain starter. J. Dairy Sci. 96:4212-4222.

CRC. 2009. CRC Handbook of Chemistry and Physics: A Ready-Reference Book of Chemical and Physical Data. 90th ed. CRC Press, Boca Raton, FL.

Crow, V. L., B. Curry, and M. Hayes. 2001. The ecology of nonstarter lactic acid bacteria (NSLAB) and their use as adjuncts in New Zealand Cheddar. Int. Dairy J. 11:275-283.

Dacre, J. C. 1953. Cheddar cheese flavour and its relation to tyramine production by lactic acid bacteria. J. Dairy Res. 20:217-223.

Degnan, B. A., and G. T. MacFarlane. 1991. Glucose dependent uptake of arabinose in Bifidobacterium breve. J. Appl. Bacteriol. $71: 28-29$.

Fred, B. Y., W. H. Peterson, and J. A. Anderson. 1921. The characteristics of certain pentose-destroying bacteria, especially as concerns their action on arabinose and xylose. J. Biol. Chem. 48:385-411.

Gobbetti, M., A. Corsetti, and J. Rossi. 1995. Maltose-fructose cofermentation by Lactobacillus brevis subsp. lindneri CB1 fructosenegative strain. Appl. Microbiol. Biotechnol. 42:939-944. 
Golnazarian, C. 2001. Slit formation in Cheddar cheese: A comprehensive investigation of the microbiological parameters associated with this defect. PhD Thesis. University of Vermont, Burlington.

Jordan, K. N., and T. M. Cogan. 1993. Identification and growth of non-starter lactic acid bacteria in Irish Cheddar cheese. Ir. J. Agric. Food Res. 32:47-55.

Kask, S., K. Adamberg, A. Orlowski, F. K. Vogensen, P. L. Moller, Y. Ardö, and T. Paalme. 2003. Physiological properties of Lactobacillus paracasei, L. danicus, and L. curvatus strains isolated from Estonian semi-hard cheese. Food Res. Int. 36:1037-1046.

Khalid, N. M., and E. H. Marth. 1990. Lactobacilli-Their enzymes and role in ripening and spoilage of cheese: A review. J. Dairy Sci. 73:2669-2684.

Koort, J., A. Murros, T. Coenye, S. Eerola, P. Vandamme, A. Sukura, and J. Björkroth. 2005. Lactobacillus oligofermentans sp. nov., associated with spoilage of modified-atmosphere-packaged poultry products. Appl. Environ. Microbiol. 71:4400-4406.

Laleye, L. C., R. E. Simard, B. H. Lee, R. A. Holley, and R. Giroux. 1987. Involvement of heterofermentative lactobacilli in development of open texture in cheese. J. Food Prot. 50:1009-1012.

Lane, C. N., P. F. Fox, E. M. Walsh, B. Folkertsma, and P. L. H. McSweeney. 1997. Effect of compositional and environmental factors on the growth of indigenous and non-starter lactic acid bacteria in Cheddar cheese. Lait 77:561-573.

Martley, F. G., and V. L. Crow. 1993. Interaction between nonstarter microorganisms during cheese manufacture and ripening. Int. Dairy J. 3:461-483.

Mullan, W. M. A. 2000. Causes and control of early gas production in Cheddar cheese. Int. J. Dairy Technol. 53:63-68.

Michel, V., and F. G. Martley. 2001. Streptococcus thermophilus in cheddar cheese-production and fate of galactose. J. Dairy Res. $68: 317-325$.

Naylor, J., and M. E. Sharpe. 1958. Lactobacilli in Cheddar cheese. III. The source of lactobacilli in cheese. J. Dairy Res. 25:431-438.

Neidhardt, F. C., J. L. Ingraham, and M. Schaechter. 1990. Page 141 in Physiology of the Bacterial Cell: A Molecular Approach. Sinauer Associates, Sunderland, MA.
Oberg, C. J., L. V. Moyes, M. J. Domek, C. F. Brothersen, and D. J. McMahon. 2011. Survival of probiotic adjunct cultures in cheese and challenges in their enumeration using selective media. J. Dairy Sci. 94:2220-2230.

Okada, S., Y. Suzuki, and M. Kozaki. 1978. A new heterofermentative lactobacillus species with meso-diaminopimelic acid in peptidoglycan, Lactobacillus vaccinostercus KOZAKI and OKADA sp. nov. J. Gen. Appl. Microbiol. 25:215-221.

Peterson. S. D., and R. T. Marshall. 1990. Nonstarter lactobacilli in Cheddar cheese: A review. J. Dairy Sci. 73:1395-1410.

Rapposch, S., F. Eliskases-Lechner, and W. Ginzinger. 1999. Growth of facultatively heterofermentative lactobacilli on starter cell suspensions. Appl. Environ. Microbiol. 65:5597-5599.

Somers, E. B., M. E. Johnson, and A. C. L. Wong. 2001. Biofilm formation and contamination of cheese by nonstarter lactic acid bacteria in the dairy environment. J. Dairy Sci. 84:1926-1936.

Thomas, T. D. 1987. Cannibalism among bacteria found in cheese. NZ J. Dairy Sci. Technol. 22:215-219.

Tinson, W., M. F. Ratcliff, A. J. Hillier, and G. R. Jago. 1982. Metabolism of Streptococcus thermophilus. 3. Influence on the level of bacterial metabolites in Cheddar cheese. Aust. J. Dairy Technol. $37: 17-21$.

Turner, K. W., R. C. Lawrence, and J. Lelievre. 1986. A microbiological specification for milk for aseptic cheese making. N.Z. J. Dairy Sci. Technol. 21:249-254.

Westby, A. 1989. Lactobacillus plantarum as a microbial antagonist PhD Thesis. University of Reading, Reading, UK.

Westby, A., L. Nuraida, J. D. Owens, and P. A. Gibbs. 1993. Inability of Lactobacillus plantarum and other lactic acid bacteria to grow on D-ribose as sole source of fermentable carbohydrate. J. Appl. Bacteriol. 75:168-175.

White, D. 2007. The Physiology and Biochemistry of Prokaryotes. 3rd ed. Oxford University Press, New York, NY. 